УДК $327.8(620: 5)$ «21»

DOI: 10.26693/ahpsxxi2019.01.147

\title{
УЧАСТЬ АРАБСЬКОЇ РЕСПУБЛІКИ СГИПЕТ У ПРОТИДІЇ ТЕРОРИЗМУ НА БЛИЗЬКОМУ СХОДІ ЗА ПРЕЗИДЕНТСТВА А. Ф. АС-СІСІ
}

\author{
Ірина Тихоненко, \\ e-mail:irinavi2202@gmail.com \\ ORCID https://orcid.org/oooo-ooo2-7716-085X \\ Чорноморський національний університет імені Петра Могили, \\ Украӥна, 540о3, м. Миколаӥв, вул. 68 Десантників, 10 \\ Юлія Христодорова, \\ e-mail:juliannaaa96@gmail.com \\ ORCID https://orcid.org/oooo-ooo2-7716-3014 \\ Чорноморсъкий національний університет імені Петра Могили, \\ Украӥна, 540о3, м. Миколаїв, вул. 68 Десантників, 10
}

У статті здійснено спробу аналізу участі Єгипту в протидї тероризму на Близькому Сході, що визначено одним із пріоритетів зовніиньополітичної стратегї держави за президентства А. Ф. ас-Сісі. Виявлено, що зовнішня політика Єгипту детермінуеться проблемами внутрішньополітичного розвитку після подій «Арабської весни». У протидї тероризму у регіоні Єгипет долучаеться до міждержавного співробітництва, бере участь у спільних військових навчаннях, антитерористичних операціях. Зокрема, заручившись підтримкою впливових крайн в регіоні (Арабські Емірати та Саудівська Аравія) намагається посилити свій авторитет на Близъкому Сході.

Ключові слова: Єzипет, Саудівсъка Аравія, Близький Схід, регіональна безпека, тероризм

Постановка проблеми. Близькосхідний регіон є зоною конфліктогенності у системі міжнародних відносин, яка впливає на формування зовнішньополітичного курсу та пріоритетів як регіональних, так і позарегіональних акторів. Винятком не є й Арабська Республіка Єгипет (АРЄ), яка протягом декількох століть виконувала важливу функцію культурного і політичного синтезу між ісламом і християнством, арабським світом і Європою, Африкою і Азією, а останнім часом у зв'язку із «Арабською весною» стала певним каталізатором змін у регіоні. Тому, після подій «Арабської весни», відновлення балансу у регіоні та збереження статусу впливової держави $є$ пріоритетом для Єгипту на сучасному етапі. Підтвердженням чого є заяви президента Єгипту А. Ф. ас-Сісі щодо відновлення держави та їі інститутів, яке має сприяти зменшенню терористичної загрози, фрагментації держав регіону з етнічних чи сектантських причин, на чому він наголосив у січні 2020 році на зустрічі з Президентом Європейської Ради Ш. Мішелем․ Тому, протидія терористичній загрозі та стримування низки терористичних організацій, що діють на території держав Близького Сходу $є$ одним із пріоритетів єгипетської політики.

Ступінь наукової розробки проблеми. Близькосхідний регіон є об’єктом дослідження низки науковців одне із центральних місць у якому посідає аналіз зовнішньополітичної стратегії Єгипту. Серед українських фахівців дослідженням зовніш-

\footnotetext{
${ }^{1}$ State Information Service. (2020). Sisi: Egypt eyes further EU cooperation against illegal migration, terrorism. Retrieved from http://www.sis.gov.eg/Story/143354/Sisi-Egypt-eyes-further-EUcooperation-against-illegal-migration\%2C-terrorism?lang=en-us
} 
ньої політики Єгипту займаються В.Й. Разіцький 3 , Л.Л. Кияниця4.

Серед російських дослідників, які вивчають регіональний рівень зовнішньої політики Єгипту є праці А.В. Калашникової5 та О.О. Пойди

Західні фахівці-міжнародники - британський дослідник Дж. Браун7 та американський дослідник Б. Барфі ${ }^{8}$ - приділяють значну увагу релігії та релігійним угрупуванням в Єгипті, а також їх терористичній складовій.

Професор політології та директор Центру міжнародних досліджень в Каїрському університеті М. Камаль відзначає роль близькосхідної політики АРЄ як для держави, так і для регіону в цілому9.

Мета статті полягає у аналізі участі Арабської Республіки Єгипет у протидії терористичній загрозі на Близькому Сході на сучасному етапі, зокрема, охарактеризувавши близькосхідний вектор зовнішньополітичної стратегії Єгипту за президентства А. Ф. ас-Сісі, регіональну конфліктогенність та діяльність Єгипту у боротьбі із терористичною загрозою у регіону.

Сучасний Близький Схід зі збільшенням його геостратегічного та геоекономічного значення, а також дестабілізуючими процесами в контексті так званої «Арабської весни» можна вважати найбільш конфліктогенною зоною світового простору. Цей регіон, який все частіше у вітчизняній і зарубіжній науковій літературі називають Великим Близьким Сходом, включаючи в нього території, що тягнуться від Афганістану на сході до Марокко на заході, і від Ірану на півночі до Ємену на півдні, є постійним джерелом загроз міжнародній безпеці, таких як тероризм, розповсюдження зброї масового знищення (ЗМЗ), збройних регіональних та внутрішньодержавних конфліктів ${ }^{10}$.

Вважається, що територія Близького Сходу розташована в основному в ПівденноЗахідній Азії і Північно-Східній Африці, але при цьому існують підходи за якими частина регіону розташована в Європі (територія Туреччини). Зокрема, до поняття «Близький Схід» входять території навколо південних і східних берегів Середземного моря, що простягаються від Марокко до Аравійського півострова і Ірану, і навіть іноді включаються сусідні землі. Як правило, Схід ділиться на три регіони: Близький, Середній і Далекий Схід ${ }^{11}$.

\footnotetext{
${ }^{2}$ Бовсунівський, П.В. (2010). Зовнішня політика Єгипту: балансування в боротьбі за регіональне лідерство. Наукові записки Інституту політичних і етнонаціональних досліджень ім. І.Ф. Кураса НАН Украӥни, 48, 461-469.

3 Петренко, В.В., Разіцький, В.Й. (2014). Особливості правління «Братів-мусульман» в Єгипті та причини їхньої поразки. Вісник Київського національного університету імені Тараса Шевченка, Філософія. Політологія, 2, 6-49.

4 Кияниця, Л.Л. (2015). Трансформація регіональної політики Єгипту в контексті «арабської весни». Міжнародні відносини Серія «Політичні науки». Retrieved from http://journals.iir.kiev.ua/index.php/pol_n/article/viewFile/2486/2217

5 Калашникова, А.В. (2014). Влияние социально-экономических факторов на внешнеполитическую стратегию Египта в период политической нестабильности. Вестник РГГУ. Серия: Политология. История. Международные отношения, 7, 256-264.

6 Пойда, А.А. (2018). Исторические детерминанты внешней политики Арабской Республики Египет. Вестник Российского университета дружбы народов. Серия: Всеобщая история, 2, 192-200.

7 Brown, J. (2011). Salafis and Sufis in Egypt's Retrieved from https://carnegieendowment.org/2011/12/20/salafis-and-sufis-in-egypt-pub-46278

8 Barfi, B. (2018). Egypt's New Realism: Challenges Under Sisi. Washington: Washington Institute for Near East Policy, 98.

9 Kamal, M. (2018). The Middle East According to Egypt. The Cairo Review of Global Affairs, 29, 7077. Retrieved from https://www.thecairoreview.com/essays/the-middle-east-according-to-egypt/

10 Абалян, А.И. (2013). Анализ основных источников конфликтов в Ближневосточном регионе. Политическая экспертиза: ПОЛИТЭКС, 2, 71-79.

${ }^{11}$ East. (1991). In The New Encyclopedia Britannica (p. 1044). Ottawa: Menage, 8.
} 
Треба відзначити, що саме адміністрація США зробила значний внесок в розширення трактування кордонів регіону. Так в ході саміту «Великої вісімки» в 2004 р. президент США Дж. Буш ввів в політичний лексикон новий термін - «Великий Близький Схід» (Greater Middle East). Цим терміном було позначено величезні території: арабські країни, держави Центральної Азії та Південного Кавказу, Туреччини, Ірану, Афганістану і Пакистану12.

Такі різнобічні підходи до визначення Близькосхідного регіону виправдовуються взаємозалежністю та залученістю до регіональних процесів, які здебільшого мають конфліктне підгрунтя, низки держав. Унікальність географічного розташування Єгипту, геополітичного значення та статус одного з центрів ісламського світу дозволяє єгипетському керівництву реалізовувати багатовекторну зовнішню політику. Проте, серед геополітичних переваг вирізняється контроль над Синайський півостровом, а також привілейованість Близькосхідного регіону.

Зовнішня політика Єгипту за останні три десятиліття була спрямована на вирішення двох основних завдань: як стримати амбіції Ізраїлю і як вирішити палестинську проблему, яка є ядром близькосхідної кризи. Це завдання є досить складним через низку факторів: від структурних особливостей конфлікту до розбіжностей у засобах реалізації політики арабськими державами і підходами до проблеми ${ }^{13}$. У свою чергу, проблема близькосхідного врегулювання, яку можна розглядати як у вузькому (арабоізраїльське протистояння) так і широкому (конфлікти, що детермінують регіональну нестабільність) сенсах все більше пов’язана із терористичною загрозою.

Після приходу до влади у Єгипті А. Ф. ас-Сісі були внесені певні корективи у зовнішньополітичну стратегію держави. Зокрема, у інавгураційній промові 2014 року президент АРЄ заявив, що Єгипет прагне встановити владу і прагне захистити мир, а не агресію; відстоюючи справедливість, прагне викорінити тероризм і поширити натомість безпеку як в країні, так і в регіоні ${ }^{14}$.

Ас-Сісі також відзначає, що Єгипет увійде в історію як захисник арабської нації та ісламу. «Головне завадити іншим виконувати схеми, заплановані проти безпеки та територіальної цілісності, і захистити іслам як релігію від того, щоб її асоціювали 3 насильством та тероризмом. Нехай буде відомо, що відносини з нашими братами в арабському світі перевищують економічну вигоду, військове співробітництво та координацію безпеки», - зазначив президент Єгипту 15.

Протидія тероризму стала пріоритетом зовнішньої політики офіційного Каїру. А. Ф. ас-Сісі заявив, що неможливо передбачити майбутнє регіонального порядку без остаточного та всебічного протистояння тероризму. Він пов'язує підйом терористичних організацій з дезінтеграцією та нестабільністю державних інститутів в арабському регіоні, і те, що він назвав систематичними спробами перетягнути регіон у «руйнівний вакуум». Він також підкреслив важливість вирішення палестинського питання через справедливе, всеосяжне та остаточне врегулювання на основі дводержавних рамок. А. Ф. ас-Сісі вважає, що врегулювання палестинського питання усуне головний привід, який терористи використовують для виправдання своїх злочинів ${ }^{16}$.

Тому, важливим чинником, що дозволить викорінити тероризм як загрозу стабільності на Близькому Сході є розбудова стабільних державотворчих процесів у дер-

12 Евсеев, В.В. (2013). Концепция «Большой Ближний Восток» под углом национальной безопасности. Национальная безопасность, 4 (27), 621.

13 Пойда, А.А. (2018). Указ. раб., 193.

14 State Information Services. (2014, June 14). Statement by President Abdel Fattah El Sisi at ceremony marking his inauguration. Retrieved from http://www.sis.gov.eg/Story/78371/Statement-byH.E.President-Abdel-Fattah-El-Sisi-at-the-ceremony-marking-his-inauguration-at-Qasr-el-Qubba-

Palace-(June-8\%2c-2014)?lang=en-us

${ }^{15}$ State Information Services Egypt. (2014, June 30). Speech of H.E.President Abdel fattah al-Sisi on the First Anniversary of the June 30 Revolution Monday. Retrieved from http://www.sis.gov.eg/Story/78609/Speech-of-H.E.President-Abdel-fattah-al-Sisi-on-the-First-

Anniversary-of-the-June-30-Revolution-Monday\%2C-June-30\%2C-2014?lang=en-us

${ }^{16}$ Kamal, M. (2018). Op. cit., 74. 
жавах регіону та подолання криз і конфліктів, які вже мають місце і до яких залучені терористичні угрупування. У свою чергу, дії Єгипту у протидії тероризму, відновленню державотворчих процесів розгортаються як на двосторонній міждержавній основі, так у межах міжнародних організацій.

Єгипет як член ООН відіграє значну роль у підтримці міжнародного миру та безпеки, сприяючи посиленню міжнародних дій для досягнення колективної безпеки та відстоювання цілей, закріплених у Цілях та принципах ООН. Тому, офіційний Каїр $\epsilon$ активним учасником миротворчих операцій ООН. Перший внесок Єгипту в підтримку миру ООН відбувся у 1960 р. в Конго. 3 того часу Єгипет зробив внесок у 37 місій ООН з понад 30 ооо миротворців, розміщених у 24 країнах Африки, Азї, Латинської Америки та Європи 17.

Немає сумнівів, що арабський регіон є більш вразливим до терористичної загрози та загострення конфліктів. Збереження сили держави та реформи є основним пріоритетом зовнішньої політики Єгипту в арабському регіоні. На думку Єгипту, кризи в Сирії та Ємені не мають іншого варіанту врегулювання, крім відновлення національної держави, збереження ㄲï суверенітету та цілісності її інституцій, досягнення законних прагнень своїх громадян. Єгипет стоїть на підтримці політичного рішення, яке проводить Організація Об’єднаних Націй у цих двох країнах, і відкидає будь-яку експлуатацію криз в Сирії та Ємені як засіб досягнення регіональних амбіцій та втручання терористичних та екстремістських організацій ${ }^{18}$.

Єгипет віддає пріоритет налагодженню партнерства з країнами Арабської затоки, зокрема Саудівською Аравією та Об’єднаними Арабськими Еміратами. Ас-Сісі наголосив, що безпека Арабської затоки є невід'ємною частиною безпеки Єгипту, а загрози безпеці Перської затоки є пріоритетними для подолання для Єгипту. Він також охарактеризував відносини з Саудівською Аравією та Об'єднаними Арабськими Еміратами як «глибокі та стратегічні», що входять до національних інтересів трьох країн та безпеці в цілому. Ас-Сісі кілька разів стверджував, що Саудівська Аравія та Єгипет - це два крила національної безпеки арабської держави ${ }^{19}$.

У 2015 р. Єгипет приєднався до «Ісламської антитерористичної коаліції» ініційованої саме Саудівською Аравією. Коаліція з 34 переважно мусульманських країн створена для координації боротьби з терористичними організаціями. Держави співпрацюють разом з метою протидії будь-якій терористичній організації, а не лише «Ісламській державі» у країнах, включаючи Ірак, Сирію, Лівію, Єгипет та Афганістан ${ }^{20}$.

Тому, Каїр активно бере участь у регіональному співробітництві щодо протидії тероризму. У 2016 р. Єгипет взяв участь у навчанні «Грім Півночі», яке передбачає участь наземних, повітряних та військово-морських сил. Збройні сили 320 країн розпочали маневри на північному сході Саудівської Аравії, які офіційне агентство Саудівської преси (SPA) назвало одним із найбільших військових навчань у світі. Головною метою навчань було покращити підготовку у відповідь на загрозу, яку представляють терористичні групи ${ }^{21}$.

Варто наголосити, що з огляду на внутрішньополітичну ситуацію і питання участі Єгипту у регіональних конфліктах, Каїр мав дещо обмежений або вибірковий підхід

\footnotetext{
${ }^{17}$ State Information Service. (n.d.). Egypt and Peacekeeping. Retrieved from http://www.sis.gov.eg/section/o/8332?lang=en-us

${ }^{18}$ State Information Service. (n.d.). Egypt's foreign policy towards Arab crises. Retrieved from http://www.sis.gov.eg/section/7302/9413?lang=en-us

19 Косач, Г.Г. (2015). Эволюция внешней политики Саудовской Аравии после«Арабской весны». Вестник Нижегородского университета им. Н.И. Лобачевского, 3, 53.

${ }^{20}$ Saudi Arabia forms Muslim 'anti-terrorism' coalition. (2015, December 15). Al Jazeera. Retrieved from https://www.aljazeera.com/news/2015/12/saudi-arabia-forms-muslim-anti-terrorismcoalition-151215035914865.html

${ }^{21}$ Saudis conduct military exercises with 20 states. (2016, February 28). Al Jazeera. Retrieved from https://www.aljazeera.com/news/2016/o2/saudi-conducts-military-exercises-20-states160228095249237.html
} 
до врегулювання регіональних криз. Наприклад, у 2015 р. Єгипет брав участь в операції «Вирішальний шторм» - військове втручання коаліції мусульманських країнсунітів, в тому числі країн Ради співробітництва арабських держав Перської Затоки Марокко, Судану, Йорданії і Пакистану, проти угруповань Хуті в Ємені. Проте, Єгипет оголосив, що його участь в операції обмежувалася тільки повітряними і військово-морськими силами, підкреслюючи відсутність сухопутних сил, з головною метою забезпечення вільного судноплавства через Червоне море і протоку Баб-аль-Мандаб.

Для Єгипту важливою складовою забезпечення регіональної безпеки $\epsilon$ підтримка стабільності інститутів держави у сусідніх країнах і як результат - недопущення поширення терористичної загрози. Така позиція знайшла свою реалізацію щодо кризи в Лівії, а саме, охорони прикордонних районів та моніторингу діяльності терористичних організацій з метою забезпечення безпеки прикордонної смуги. Єгипет також працює над тим, щоб Лівія не стала новим об’єктом для залучення терористів та екстремістів у регіоні, особливо зважаючи на втрати в Іраку та Сирії величезних територій. Це було однією з головних причин підтримки Єгиптом спадкоємця Хафатера та Лівійської національної армії з початку операції «Гідність» у 2014 році ${ }^{22}$. Наприклад, у травні 2017 року єгипетські винищувачі почали наносити удари по таборам в лівійському місті Дерна, де, як визначив Каїр, проходили підготовку бойовики, які вбили десятки християн-коптів, що прямують до монастиря на півдні Єгипту23.

Єгипет також висловив глибоку стурбованість можливим відокремленням курдських частин північного Іраку після референдуму про незалежність, який відбувся 25 вересня 2017 р. Єгипетське міністерство закордонних справ закликало всі сторони проявляти координованість зусиль, так як односторонні заходи можуть ускладнити ситуацію та ще більше дестабілізувати ситуацію як в Іраку, так і збільшити напругу в регіоні.

Варто зауважити, що Єгипет має досвід посередництва у врегулюванні конфліктів в регіоні за участі терористичних організацій. Зокрема, у Сирії, коли криза прийняла напрям умиротворення, Каїр відігравав роль посередництва між сирійською армією та опозиційними фракціями, крім фронту «Аль-Нусра» та легіону «Аль-Рахман», оскільки Каїр виключив угруповання, до екстремістських терористичних організацій.

Більше того, на думку Єгипту, національні армії є ключовими гравцями у збереженні держави. В інтерв’ю газеті «Ашарк Аль-Авсат» у листопаді 2017 р. ас-Сісі підсумував свою позицію, підкресливши свою відмову від збройних ополчень, що занурюють нації у нескінченні війни. 3 іншого боку, він підтвердив свою підтримку як для сирійської, так і для лівійської національних армій в інтерв’ю португальському каналу RTP. На запитання, чи відправить єгипетських миротворців до Сирії за мирною угодою, він відповів, що краще, щоб національна армія взяла на себе відповідальність і що його пріоритет - підтримка національної армії Сирії. Отже, Єгипет не бачить місця для недержавних суб’єктів, таких як терористичні групи, у вирішенні регіональних конфліктів. Президент Єгипту А.Ф. ас-Сісі закликав «розібрати» ці групи, а не інтегрувати їх у державу24.

Загроза «Братів-мусульман» зумовлює сучасний зовнішньополітичний курс Єгипту. Природним союзником в боротьбі з терористами виступає Саудівська Аравія. Відчуваючи протягом багатьох років політико-ідеологічне протистояння з «Братамимусульманами», Саудівська Аравія змушена об’єднуватися з Єгиптом, Об’єднаними Арабськими Еміратами. Основними суперниками за лідерство в близькосхідному регіоні для союзників Єгипту і Саудівської Аравї̈ є Туреччина і Катар, які підтримують «Братів-мусульман» та інші ісламістські радикальні угруповання.

${ }^{22}$ State Information Service. (n.d.). Egypt's foreign policy towards Arab crises. Retrieved from http://www.sis.gov.eg/section/7302/9413?lang=en-us

23 Пойда, А.А. (2018). Исторические детерминанты внешней политики Арабской Республики Египет. Вестник Российского университета дружбы народов. Серия: Всеобщая история, 2, 96. 24 Kamal, M. (2018). Op. cit., 74-75. 
Конфлікт Саудівської Аравії з «Братами-мусульманами» триває протягом декількох десятиліть. Ідеологічні розбіжності призвели до безперервної боротьби «Братівмусульман» і саудівців. Ця протидія призвела до так званої Катарської кризи. Використовуючи протестні акції «Братів-мусульман» в період «Арабської весни» 20112012 рр., Катар підтримував різні ісламістські радикальні угруповання. Саудівська Аравія, звинувачуючи Катар в підтримці тероризму, кинула йому виклик - початок розриву із ним дипломатичних відносин низки арабських держав у 2017 році. Єгипет приєднався до Саудівської Аравії, Об'єднаних Арабських Еміратів та Бахрейну в бойкотуванні Катару. Чотири держави звинуватили катарську владу у підтримці та фінансуванні тероризму, утримуванні екстремістів, поширенні ненависті та втручанні у внутрішні справи інших країн. Під час зустрічі з американською делегацією, міністр закордонних справ Єгипту, Самех Шукрі підкреслив, що Катар все ще підтримує терористів і не виконує поставлені вимоги 25.

Тому, можна помітити, що серед близькосхідних держав все ще немає єдності у протидії тероризму і формування єдиного погляду на те, які ж організації є терористичними чи політичними як спільно ним протидіяти.

APE також відновив свої зусилля для досягнення палестинського примирення між суперницькими угрупованнями «Хамас» $\mathrm{i}$ «Фатах». 12 жовтня 2017 р. в Каїрі обидва угрупування підписали угоду про примирення, за посередництва Єгипту. Адміністрація ас-Сісі також допомогла зняти напругу між Ліваном та Саудівською Аравією та сприяла поверненню прем’єр-міністра Саада Харірі до Бейрута ${ }^{26}$.

Терористична складова регіонального безпекового середовища на Близькому Сході стає підгрунтям до диверсифікації двосторонніх відносин Єгипту. Таким прикладом є єгипетсько-ізраїльські відносини на сучасному етапі, які від «крихкого миру» прийшли до стану «таємного союзу». Про це свідчать факти спільної операції єгипетських та ізраїльських військ проти бойовиків на Синаї. I хоча багато єгиптян розглядають Ізраїль як потенційну загрозу і співчувають палестинцям, нинішня ситуація боротьби з тероризмом змушує зберігати взаємодію між країнами.

Єгипет також активно бере участь в арабському комітеті на підтримку палестинського справи. Поряд з міжнародним співтовариством і регіональними державами, Єгипет координує зусилля по врегулюванню конфлікту, пов'язаного з визнанням Єрусалиму столицею Ізраїлю27.

Єгипет традиційно розвивав багатовекторну політику, проте саме ослаблене внутрішньополітичне середовище і низка загроз національній безпеці разом з соціальноекономічними питаннями призвели до зовнішньополітичних поступок і відходу від своєї лідируючої ролі в регіоні. Кластер проблем диктує необхідність реформ і пошук фінансової підтримки ззовні, що і веде країну по шляху обмеження самостійності у зовнішній політиці.

Висновки. Після «Арабської весни» 2011 р. Близький Схід вважається особливо конфліктогеним регіоном. Єгипет дотримується стратегічної політики, заснованої на допомозі арабським країнам подолати свої кризи, щоб досягти безпеки та стабільності в регіоні та, як результат, зміцнити національну безпеку з акцентом на принципі мирного врегулювання суперечок.

Президент АРЄ А. Ф. ас-Сісі висловлює глибоке занепокоєння з приводу діяльності терористичних організацій в регіоні. На його думку, для ефективної протидії потрібно діяти в коаліції та зупинити джерела фінансування тероризму. Головними союзниками у цій боротьбі є Саудівська Аравія та Об’єднані Арабські Еміратами. Проте, такі «союзницькі» відносини хоч і розвиваються під гаслом боротьби з тероризмом, але не можуть бути у повній мірі охарактеризовані як партнерські.

25 Егорова, Е. (2018). Внешнеполитические приоритеты Египта на современном этапе (20142018). РСМД. $\quad$ Retrieved from:https://russiancouncil.ru/blogs/ekaterinaegorova/vneshnepoliticheskie-prioritety-egipta-na-sovremennom-etape-20142018/

${ }^{26}$ Kamal, M. (2018). Op. cit., 72-73.

27 Егорова, Е. (2018). Указ. раб. 
Офіційний Каїр бере активну участь у військових операціях проти терористичних угрупувань на Близькому Сході, як на двосторонній міждержавній основі, так і на загальнорегіональному рівні (операція «Вирішальний шторм» у Ємені та участь у «Ісламській антитерористичній коаліції»). Проте, офіційний Каїр наголошує на важливості не лише протидії тероризму, а й зміцнення державних інститутів у країнах регіону, у чому провідну роль мають відіграти національні армії.

Відзначимо, що АРЕ приєднався до бойкотування Катару, що фінансово підтримував терористичні угруповання на Близькому Сході. У свою чергу, Каїр намагається бути посередником у врегулюванні регіональних конфліктів із терористичною складовою, що стає проявом багатовекторної і певним чином стриманої зовнішньополітичної діяльності на сучасному етапі.

\section{REFERENCES}

Abalian, A.I. (2013). Analiz osnovnykh istochnikov konfliktov v Blizhnevostochnom regione. [Analysis of the main sources of conflict in the Middle East]. Politicheskaia ekspertiza: POLITEKS, 2, 71-79. [in Russian]

Barfi, B. (2018). Egypt's New Realism: Challenges Under Sisi. Washington: Washington Institute for Near East Policy. [in Ehglish]

Bovsunivskyi, P.V. (2010). Zovnishnia polityka Yehyptu: balansuvannia v borotbi za rehionalne liderstvo [Egypt's Foreign Policy: Balancing the Struggle for Regional Leadership]. Naukovi zapysky Instytutu politychnykh i etnonatsionalnykh doslidzhen im. I.F. Kurasa NAN Ukrainy, 48, 461-469. [in Ukrainian]

Brown, J. (2011). Salafis and Sufis in Egypt's. Retrieved from https://carnegieendowment.org/2011/12/20/salafis-and-sufis-in-egypt-pub-46278 [in Ehglish]

Egorova, E. (2018, 28 maia). Vneshnepoliticheskie prioritety Egipta na sovremennom etape (20142018). [Egypt's foreign policy priorities at the present stage]. Retrieved from https://russiancouncil.ru/blogs/ekaterina-egorova/vneshnepoliticheskie-prioritety-egipta-nasovremennom-etape-20142018/ [in Russian]

East. (1991). In The New Encyclopedia Britannica (p. 1044). Ottawa: Menage, 8.

Evseev, V.V. (2013). Kontseptsiia «Bolshoi Blizhnii Vostok» pod uglom natsionalnoi bezopasnosti. [The Greater Middle East Concept From the Angle of National Security]. Natsionalnaia bezopasnost, 4 (27), 620-628. [in Russian]

Kalashnikova, A.V. (2014). Vliianie sotsialno-ekonomicheskikh faktorov na vneshnepoliticheskuiu strategiiu Egipta $\mathrm{v}$ period politicheskoi nestabilnosti. [The influence of socio-economic factors on the foreign policy strategy of Egypt during the period of political instability]. Vestnik RGGU. Seriia Politologiia. Istoriia. Mezhdunarodnye otnosheniia, 7, 256-264. [in Russian]

Kamal, M. (2018). The Middle East According to Egypt. The Cairo Review of Global Affairs, 29, 7077. Retrieved from https://www.thecairoreview.com/essays/the-middle-east-according-to-egypt/ [in English]

Kosach, G.G. (2015). Evoliutsiia vneshnei politiki Saudovskoi Aravii posle Arabskoi vesny [The evolution of Saudi Arabia's foreign policy after the Arab Spring.]. Vestnik Nizhegorodskogo universiteta im N.I. Lobachevskogo, 3, 50-62. [in Russian]

Kyianytsia, L.L. (2015). Transformatsiia rehionalnoi polityky Yehyptu v konteksti «arabskoi vesny». [Transformation of Egypt's regional policy in the context of the Arab Spring]. Mizhnarodni vidnosyny. Seriia «Politychni nauky». Retrieved from http://journals.iir.kiev.ua/index.php/pol_n/article/viewFile/2486/2217 [in Ukrainian]

Petrenko, V.V. \& Razitskyi, V.Y. (2014). Osoblyvosti pravlinnia «Brativ-musulman» v Yehypti ta prychyny yikhnoi porazky. [Features of the «Muslim Brotherhood» in Egypt and the reasons for their defeat]. Visnyk Kyivskoho natsionalnoho universytetu imeni Tarasa Shevchenka, Filosofiia, Politolohiia, 2, 6-49. [in Ukrainian]

Poida, A.A. (2018). Istoricheskie determinanty vneshnei politiki Arabskoi Respubliki Egipet [Historical determinants of foreign policy of the Arab Republic of Egypt]. Vestnik Rossiiskogo universiteta druzhby narodov, Seriia Vseobshchaia istoriia, 2, 192-200. [in Russian]

Saudi Arabia forms Muslim 'anti-terrorism' coalition. (2015, December 15). Al Jazeera. Retrieved from https://www.aljazeera.com/news/2015/12/saudi-arabia-forms-muslim-anti-terrorismcoalition-151215035914865.html [in Ehglish]

Saudis conduct military exercises with 20 states. (2016, February 28). Al Jazeera. Retrieved from https://www.aljazeera.com/news/2016/o2/saudi-conducts-military-exercises-20-states160228095249237.html [in Ehglish] 
State Information Services Egypt. (2014, June 30). Speech of H.E.President Abdel fattah al-Sisi on the First Anniversary of the June 30 Revolution Monday. Retrieved from http://www.sis.gov.eg/Story/78609/Speech-of-H.E.President-Abdel-fattah-al-Sisi-on-the-FirstAnniversary-of-the-June-30-Revolution-Monday\%2C-June-30\%2C-2014?lang=en-us [in Ehglish]

State Information Services. (2014, June 14). Statement by President Abdel Fattah El Sisi at ceremony marking his inauguration. Retrieved from http://www.sis.gov.eg/Story/78371/Statement-by-H.E.President-Abdel-Fattah-El-Sisi-at-theceremony-marking-his-inauguration-at-Qasr-el-Qubba-Palace-(June-8\%2c-2014)?lang=en-us [in Ehglish]

State Information Service. (n.d.). Egypt and Peacekeeping. Retrieved from http://www.sis.gov.eg/section/o/8332?lang=en-us [in Ehglish]

State Information Service. (n.d.). Egypt's foreign policy towards Arab crises. Retrieved from http://www.sis.gov.eg/section/7302/9413?lang=en-us [in Ehglish]

State Information Service. (2020). Sisi: Egypt eyes further EU cooperation against illegal migration, terrorism. Retrieved from http://www.sis.gov.eg/Story/143354/Sisi-Egypt-eyesfurther-EU-cooperation-against-illegal-migration\%2C-terrorism?lang=en-us [in Ehglish]

Iryna Tykhonenko, Petro Mohyla Black Sea National University, Mykolaiv, Ukraine ORCID https://orcid.org/oooo-0002-7716-085X

Yuliia Khrystodorova, Petro Mohyla Black Sea National University, Mykolaiv, Ukraine ORCID https://orcid.org/oOOO-OOO2-7716-3014

\section{Participation of the Arab Republic of Egypt in combating terrorism on the Middle East in A. F. El-Sisi Presidency}

Egypt's foreign policy priorities are determined by the problems of domestic political development, regional and world trends. The events of 2011-2012 and "Arabic spring" have led to an imbalance in the political situation in the Middle East region and determined conflict situations. This article examines Egypt's involvement in the combating terrorism in the Middle East (for instance Yemen, Syria) as a priority vector for the current President of the Arab Republic of Egypt (ARE) A. F El-Sisi.

The ARE's President El-Sisi is deeply concerned about the activities of terrorist organizations in the region. To counter this, one must act in coalition and stop the sources of terrorist financing. The main allies in this fight are Saudi Arabia and the United Arab Emirates. Cairo is actively involved in military operations against terrorist groups in the Middle East, both bilaterally and regional level (Operation in Yemen and participation in the Islamic Anti-Terrorist Coalition). However, official Cairo stresses the importance not only of counter-terrorism but also of the strengthening of state institutions in the regional countries, in which national armies play a leading role.

$A R E$ has also joined the boycott of Qatar, which has repeatedly supported financially terrorist groups in the Middle East. In turn, Cairo play the role of mediator in the resolution of regional conflicts with the terrorist component, which is a manifestation of a multilateral and somewhat restrained foreign policy activity at the present stage. For instance, the participations of Egypt in reconciliation between rival "Hamas» and «Fatah» groups in Palestine. In the Israeli-Palestinian confrontation, Egypt occupies a neutral position without provoking conflicts in the region. The authors conclude that Egypt is trying to maintain its influence as an important actor in the Middle East having allies and promoting an approach to counter terrorist groups.

Keywords: Egypt, Saudi Arabia, Middle East, regional security, terrorism 